\title{
Shallow aquifer response to climate change scenarios in a small catchment in the Guarani Aquifer outcrop zone
}

\author{
DAVI C.D. MELO and EDSON WENDLAND \\ Escola de Engenharia de São Carlos, Universidade de São Paulo, Departamento de Hidráulica e \\ Saneamento, Av. Trabalhador São-Carlense, 400, 13566-590 São Carlos, SP, Brazil
}

Manuscript received on May 4, 2016; accepted for publication on September 27, 2016

\begin{abstract}
Water availability restrictions are already a reality in several countries. This issue is likely to worsen due to climate change, predicted for the upcoming decades. This study aims to estimate the impacts of climate change on groundwater system in the Guarani Aquifer outcrop zone. Global Climate Models (GCM) outputs were used as inputs to a water balance model, which produced recharge estimates for the groundwater model. Recharge was estimated across different land use types considering a control period from 2004 to 2014, and a future period from 2081 to 2099. Major changes in monthly rainfall means are expected to take place in dry seasons. Most of the analysed scenarios predict increase of more than $2{ }^{\circ} \mathrm{C}$ in monthly mean temperatures. Comparing the control and future runs, our results showed a mean recharge change among scenarios that ranged from $\sim-80$ to $\sim+60 \%$, depending on the land use type. As a result of such decrease in recharge rates, the response given by the groundwater model indicates a lowering of the water table under most scenarios.
\end{abstract}

Key words: Climate change, Guarani Aquifer, groundwater modelling, groundwater recharge.

\section{INTRODUCTION}

The 2014 drought in Brazil became notorious mainly because it directly affected the most industrialized city in the country and the biggest South American metropolis (Romero 2015, Johnson and Jelmayer 2015). The possibility that São Paulo would run out of water showed the fragility of the current system to changes in the weather conditions. This vulnerability is shared by several regions around

Correspondence to: Davi de Carvalho Diniz Melo

E-mail:melo.dcd@gmail.com

* Contribution to the centenary of the Brazilian Academy of Sciences. the globe, and it is likely to worsen due to climate change.

Climate change can affect the hydrological cycle by altering soil water storage, groundwater recharges rates, etc (Chiew and McMahon 2002, Legesse et al. 2003, Scibek et al. 2007). Global warming is likely to alter rainfall patterns and raise evapotranspiration rates. Such changes will influence groundwater hydraulics because of their influence on water table levels and aquifer dynamics (Jyrkama and Sykes 2007, Ficklin et al. 2010).

The water crisis in São Paulo state raised the question of whether the use of groundwater 
resources would be a solution to stresses caused by climate change, in short and long term. However, it is paramount that the use of these resources is well planned and based on reliable information for creating management politics, avoiding aquifer overexploitation (Giordano 2009).

A well stablished procedure to estimate climate change impacts on groundwater is to use future scenarios to produce atmospheric forcing for hydrological models (Nakicenovic et al. 2000). These models can, in turn, be coupled to groundwater models or provide independent recharge estimates (Moustadraf et al. 2008, Rozell and Wong 2010, Liu 2011).

There have been several studies of the climate change impacts on groundwater globally (e.g., Dawes et al. 2012, McCallum et al. 2010). Several such studies assessed the impact of climate change on recharge rates (e.g., Neukum and Azzam 2012, Dawes et al. 2012, Holman 2006, Eckhardt and Ulbrich 2003, McCallum et al. 2010, Raposo et al. 2013) and/or on groundwater flow and water table levels (e.g., Dams et al. 2012, Kurylyk et al. 2014, Toews and Allen 2009). However, no similar investigation was performed for South America's most relevant aquifers such as the Guarani Aquifer.

The Guarani Aquifer System (GAS) plays an important role for four South American countries (Brazil, Argentina, Paraguay and Uruguay), providing $\sim 20$ million $\mathrm{m}^{3}$ day-1 of water (OAS/ GEF 2009). The stored volume of water in the GAS is estimated to be between 25,000 and $37,000 \mathrm{~km}^{3}$ (OAS/GEF 2009). Although the high demand for GAS groundwater is still sustainable, it demonstrates the importance of this aquifer for this continent and especially for Brazil, where the majority of GAS groundwater extraction occurs.

Despite the importance of the GAS as a potable water supply, there has been little effort by the scientific community in quantifying climate change impacts on groundwater recharge or water table levels within this aquifer's outcrop zone. Thus, the objective of this paper is to quantify the impacts of climate change scenarios on groundwater levels within a GAS recharge area.

As noted by Kurylyk and MacQuarrie (2013), many past studies have shown the importance of employing an ensemble of future scenarios, resulting in a range of possible impacts rather than a single response. This approach is very important given the uncertainties involved in the atmospheric system modelling, downscaling and hydrological modelling processes (Praskievicz and Chang 2009). Furthermore, Kurylyk and MacQuarrie (2013) suggest that the future scenarios used to estimate the impacts on groundwater should consider land cover change as well, rather than the climate conditions only, which agrees with the findings of Natkhin et al. (2012), who showed that the groundwater recharge can be equally affected by climatic and land use factors.

In this study, the projected precipitation and temperature of $10 \mathrm{GCM}$ climate scenarios for the period 2081-2099 were combined with two land use scenarios to generate recharge rates in a water budget model, which produced the inputs to a groundwater flow model. The text is organized into three main topics detailed in the methods and results sections. The first section addresses the rainfall and temperature time series extracted from multiple GCM runs. In the second section, the approach used to derive the groundwater recharge from both climate variables is described. The last section addresses the groundwater flow model calibration and its runs using future climate scenarios.

\section{STUDY AREA}

The Guarani Aquifer System exists in the Botucatu and Pirambóia stratigraphic units (Araújo et al. 1999, Rabelo and Wendland 2009, Hirata et al. 2011). The Jurassic sandstones of the Botucatu Formation are of Aeolian origin with well-sorted grains and high hydraulic conductivity. The Triassic 
sandstones of the Pirambóia Formation are of fluvio-lacustrine/aeolian origin with increased clay in the oldest layers, resulting in lower conductivity (Rabelo and Wendland 2009). The GAS is confined by the overlying basaltic rocks of the Serra Geral Formation, which is overlain by the sedimentary layers of the Bauru Group (Araújo et al. 1999, Sracek and Hirata 2002). The GAS is a confined to semi-confined aquifer with outcrop zones comprising $10 \%$ of the total area. The outcrop zones of GAS in Brazil are shown in Figure 1. Our study area lies within such an outcrop zone.

\section{THE ONÇA CREEK BASIN}

The study area, located in the central region of São Paulo state, is the Onça Creek Basin (OCB) (Figure 1). The OCB has a subtropical climate with wet summers and dry winters, mean annual temperatures of $20.5^{\circ} \mathrm{C}$ and mean annual rainfall of $1500 \mathrm{~mm}$ (1974-2013). Land use monitoring since 2000 has shown an increase of eucalyptus, citrus and crops on account of pasture and Brazilian Cerrado natural forests.

The unconfined aquifer in the OCB is formed by Cenozoic rocks belonging to São Bento Group, mainly originated from the Botucatu Formation. The Mesozoic Jurassic and Triassic rocks of GAS form the bottom of the unconfined aquifer. In this study, only the saturated thickness relative to the Cenozoic is modelled (Figure 2).

\section{MATERIALS AND METHODS}

\section{MONITORING DATA}

Water table levels were obtained from nine monitoring wells, strategically distributed under three different soil uses: citrus (orange and lemon), sugarcane and pasture. Since 2004, the water table level has been measured every 15 days using a manual gauge and, since 2007, automatic pressure transducers that provide water table depth every 12 hours were also used.
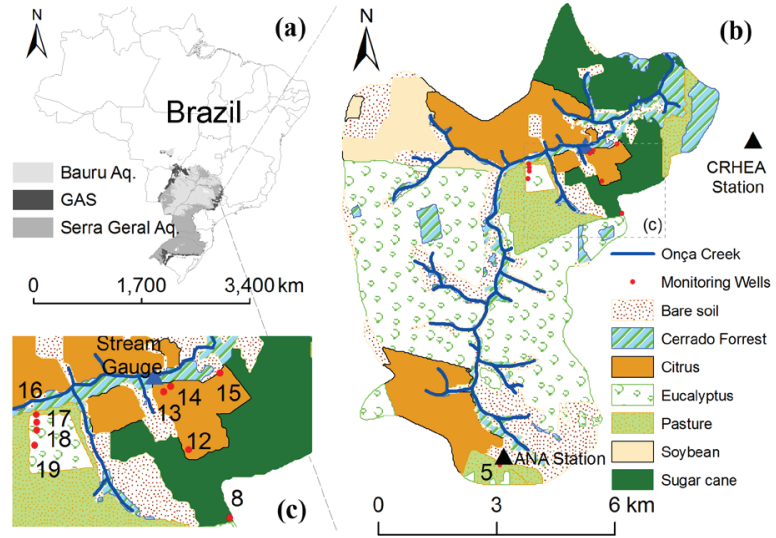

Figure 1 - Location of the Onça Creek basin (OCB) in the Guarani Aquifer System (GAS) outcrop zone in Brazil (a); 2014 land use distribution within OCB (b) and detailed map showing the monitoring wells and stream gauge location (c). Monitoring data were acquired from two stations belonging to the Centre for Water Resources and Applied Ecology (CRHEA - Centro de Recursos Hídricos e Ecologia Aplicada) and Brazilian National Water Agency (ANA - Agência Nacional de Águas).

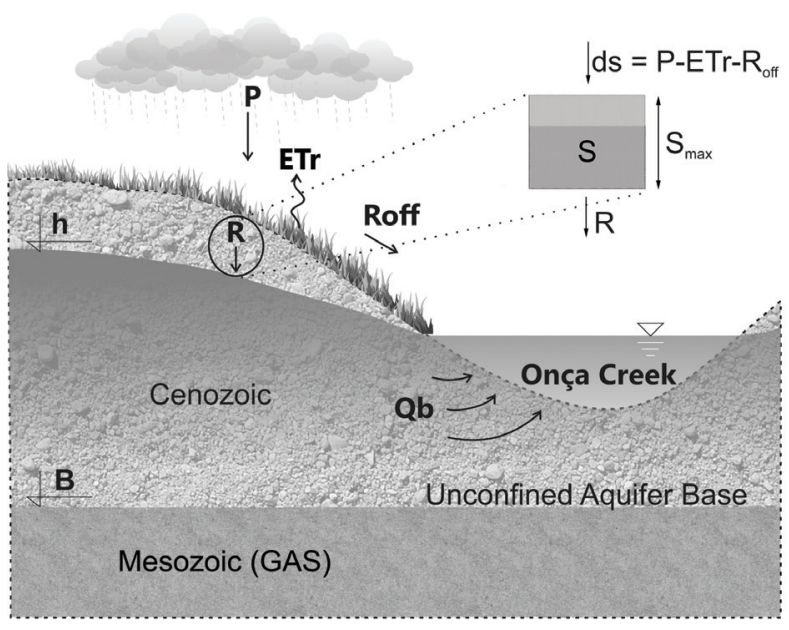

Figure 2 - Schematic drawing of a cross section in the OCB showing the unconfined aquifer modelled in SPA and water budget method used to estimate recharge.

Daily precipitation and temperature measurements are from the CRHEA/USP (Centre for Water Resources and Applied Ecology of the University of São Paulo) climatological station. This station is $\sim 7 \mathrm{~km}$ from the centre of the OCB (Figure 1). Besides the CRHEA station data, rainfall time series from ANA (Brazilian National Water 
Agency) station, located in the south of OCB, were also used as input for the water budget method.

\section{CLIMATE AND LAND USE SCENARIOS}

Climate scenarios for the period 2081-2099 were derived from $10 \mathrm{GCMs}$ used in the IPCC 4AR (Intergovernmental Panel on Climate Change 4th Assessment Report). The GCMs data were downloaded from the World Climate Research Programme's (WCRP's) website (https://esg.llnl. gov:8443/index.jsp, last access: 16 November 2015) and archived as a part of the third phase of the Coupled Model Intercomparison Project (CMIP3) (Meehl et al. 2007). The software GrADS (Grid Analysis and Display System) (http://www. iges.org/grads/, last access: 16 November 2015) was used to extract precipitation and temperature time series from the GCM data files. The models were selected based on data availability for the A2 emission scenario for the last two decades of the XXI century.

Because the GCM outputs' resolution is too coarse to be used directly at the catchment scale, the data were statistically downscaled by a simple bias correction method based on the delta factor approach, using the GCMs simulation data for the control period from 1972 to 1999 . Despite its limitations to account for projected variability, this method, also known as change factor or perturbation method, has been successfully applied in previous studies (e.g., Berg et al. 2012, Kwon et al. 2012, Teutschbein and Seibert 2012, Kidmose et al. 2013). According to Holman et al. (2009) and Willems and Vrac (2011), the delta factor method assumes that the future climate will be a disturbed version of the present climate. This is accomplished by applying multiplicative (for the precipitation) or additive (for the temperature) correction factors to climatic variables.

Here, the future series (2081-2099) were perturbed by taking into account the differences between the observed and simulated series for the control period. Thus, the bias corrected precipitation $P_{\mathrm{dv}, \mathrm{m}}$ and temperature $T_{\mathrm{dv}, \mathrm{m}}$ were obtained from Eq. 1 and Eq. 2:

$P_{\mathrm{dw}, \mathrm{m}}=P_{\mathrm{gcm}, \mathrm{m}}^{\mathrm{fut}} \times\left(\frac{\bar{P}_{\mathrm{obs}, \mathrm{m}}}{\bar{P}_{\mathrm{mcg}, \mathrm{m}}^{\mathrm{cont}}}\right)$

where $P_{g c m, m}^{f u t}$ is the precipitation simulated by the gcm model in month $m$ in the future; $\bar{P}_{\text {obs,m }}$ is the mean observed rainfall for month $m$ between 1972 and 1999; $\bar{P}_{\mathrm{mcg}, \mathrm{m}}^{\mathrm{cont}}$ is the mean simulated rainfall for month $m$ by $\mathrm{gcm}$ model for the control period (1972 to 1999). The control period was defined based on the availability of rainfall measured data as well as GCM outputs.

$T_{\mathrm{dw}, \mathrm{m}}=T_{\mathrm{gcm}, \mathrm{m}}^{\mathrm{fut}}+\left(\bar{T}_{\mathrm{obs}, \mathrm{m}}-\bar{T}_{\mathrm{mcg}, \mathrm{m}}^{\mathrm{cont}}\right)$

where $T_{g c m, m}^{f u t}$ is the temperature simulated by the $\mathrm{gcm}$ model in month $m$ in the future; $\bar{T}_{\text {obs, }}$ is the mean observed temperature for month $m$ between 1974 and $1999 ; \bar{T}_{\text {mes, }}^{\text {coon }}$ is the mean simulated temperature for month $m$ by $\mathrm{gcm}$ model for the control period (1974 to 1999). Unlike rainfall series, temperature has been measured only since 1974 at the CRHEA climatological station.

The anthropic forcing in the future was taken into account by combining the climate scenarios with a land use change that consisted in replacing the current uses by sugarcane. The reasons for choosing this scenario are two-fold. The first one is due to the already observed trend in the study area for the last 14 years. The second is economic, given that these plantings provide raw material for fuel (ethanol) industries. São Paulo is the largest sugarcane producer among all Brazilian states. It is responsible for $60.1 \%$ of the national production while the Northeast and South Central accounts for $12.6 \%$ and $27.3 \%$, respectively (Rudorff et al. 2010). 
Surface water is readily available for agricultural uses, being unnecessary to drill wells for this purpose within the study area. All the water currently used for irrigation is pumped directly from the river and there is no groundwater abstraction inside OCB. This fact was assumed to remain unchanged in the future scenarios, making the land use change the only direct anthropic influence to be considered.

\section{RECHARGE ESTIMATION}

A soil water budget method (WBM) was applied to estimate monthly groundwater recharge in the OCB and is schematically shown in Figure 2. It is assumed that the monthly rainfall $(P)$ is the only input and run-off $\left(R_{\text {off }}\right)$ and evapotranspiration $(E T r)$ make up the losses. Monthly rainfall data were obtained from CRHEA climatological station and ANA rainfall gauge. Potential evapotranspiration (PET) was calculated by combining the estimates derived from Thornthwaite's method (Thornthwaite 1948 ) with the correction approach proposed by Medeiros et al. (2012). Medeiros et al. (2012) compared Thornthwaite's PET estimates to those obtained by Penman-Monteith equation (Allen et al. 1998) in São Paulo state and proposed several regression equations to reduce errors of PET based only on temperature measurements. Crop coefficients $\left(\mathrm{K}_{\mathrm{c}}\right)$ (Allen et al. 1998) were applied to the corrected PET considering each culture type occurring within the study area.

The residual $\left(d s=P-E T \mathrm{r}-R_{\mathrm{off}}\right)$, if positive, is added to the soil water storage in the unsaturated zone. In this case, soil humidity is assumed to increase and, if it reaches a maximum water retention capacity $S_{\max }$, the surplus is computed as groundwater recharge $R$. If the residual $d s$ is negative the soil water content will supply that deficit and no recharge is computed.

Field observations of run-off inside OCB are not available for every land use. However, Machado et al. (2016) used JAMS framework to construct a distributed rainfall-runoff model of OCB, providing $R_{\text {off }}$ estimates. To account for the contribution of $R_{\text {off }}$ in the future scenarios, an empirical relationship between P and modelled $R_{\text {off }}$ was developed (Eq. 3).

$$
R_{\text {off }}=0.0002 P^{2}+0.0381 P
$$

The estimated run-off using Eq. 3 was compared to collected data from four experimental run-off plots installed $\sim 10 \mathrm{~km}$ from the centre of $\mathrm{OCB}$ and under the following land uses: sugarcane, pasture, native forest and bare soil.

Oliveira et al. (2015) calculated the run-off coefficients (total run-off divided by total rainfall) for the plots under bare soil and native forest, reporting values ranging from $0.3-86 \%$ and $0.1-$ $3 \%$, respectively. Youlton (2013) found run-off coefficients ranging from 3.6-5.1\% for pasture and 2.0-5.0 \% for sugarcane. The averaged range of run-off resulting from Eq. 3 (4-18 \%) compares well with that experimentally obtained by Oliveira et al. (2015) and Youlton (2013) (1.5-19.8 \%). As noted by Oliveira et al. (2015) and as suggested by Eq. 3, the region that encompasses the study area has high infiltration rates, which can be attributed to the soil type (sandy soil).

\section{GROUNDWATER MODEL}

The governing equation of groundwater flow in an isotropic and inhomogeneous saturated medium can be expressed by Eq. 4 (Bear 1979, Fetter 2001), where $\mathrm{K}$ is the hydraulic conductivity, $\varnothing$ is the piezometric head and $\mathrm{S}_{\mathrm{y}}$ is the specific yield of the aquifer. Eq. 4 assumes that the only source term is recharge to the aquifer (R), given that there is no pumping in the area; and $\varnothing$ refers to the saturated aquifer measured from the bottom elevation of the Cenozoic rocks to the water table elevation, i.e. $\varnothing=h-B$.

$\frac{\partial}{\partial x}\left(K \varnothing \frac{\partial \varnothing}{\partial x}\right)+\frac{\partial}{\partial y}\left(K \varnothing \frac{\partial \varnothing}{\partial y}\right)+R=S_{y} \frac{\partial \varnothing}{\partial t}$ 
The conceptual model of the groundwater system in the OCB assumes that most of the groundwater boundaries match with the watershed divisors, resulting in no-flow boundaries $\left(2^{\text {nd }}\right.$ type or Neuman boundary condition) except where the water table monitoring suggests otherwise. Drainages were set as a fluid transfer $\left(3^{\text {rd }}\right.$ type or Robin-Cauchy) boundary condition, reproducing the movement of springs locations between dry and wet periods (Figure 3). The numerical model of groundwater flow was initially constructed by Melo et al. (2015) using the Simulation of Processes Aquifers (SPA) package (Wendland 2003). SPA is a module structured package based on the Finite Element Method running under Linux environment (Rabelo and Wendland 2009). The present work extends the early studies by using future climate change scenarios and by incorporating baseflow data into the calibration process. Only the unconfined aquifer (Cenozoic layer) is modelled here.

The watershed area was discretized by a horizontal bi-dimensional mesh with $\sim 3,500$ elements (Figure 3 ). The groundwater package's pre-processing algorithms uses Dalaunay and Advancing Front triangulation (George and Seveno 1994) to generate non-structured mesh in heterogeneous medium. The grid was generated keeping a distance of $200 \mathrm{~m}$ between the contour points. The flow equation systems are solved using techniques of matrix storage, iterative (Preconditioned Conjugate Gradient) and direct algorithms (SUPER-LU) (Barrett et al. 1994). Near the monitoring wells, the mesh is refined, enabling more detailed evaluation of the water table in those regions.

Springs and smaller river sections can act as losing or gaining streams (Bear 1979, Fetter 2001). Based on the characteristics of the study area, the model was set to only allow river stretches to drain water from the aquifer and never to be a losing stream. Thus, the maximum infiltration along a river

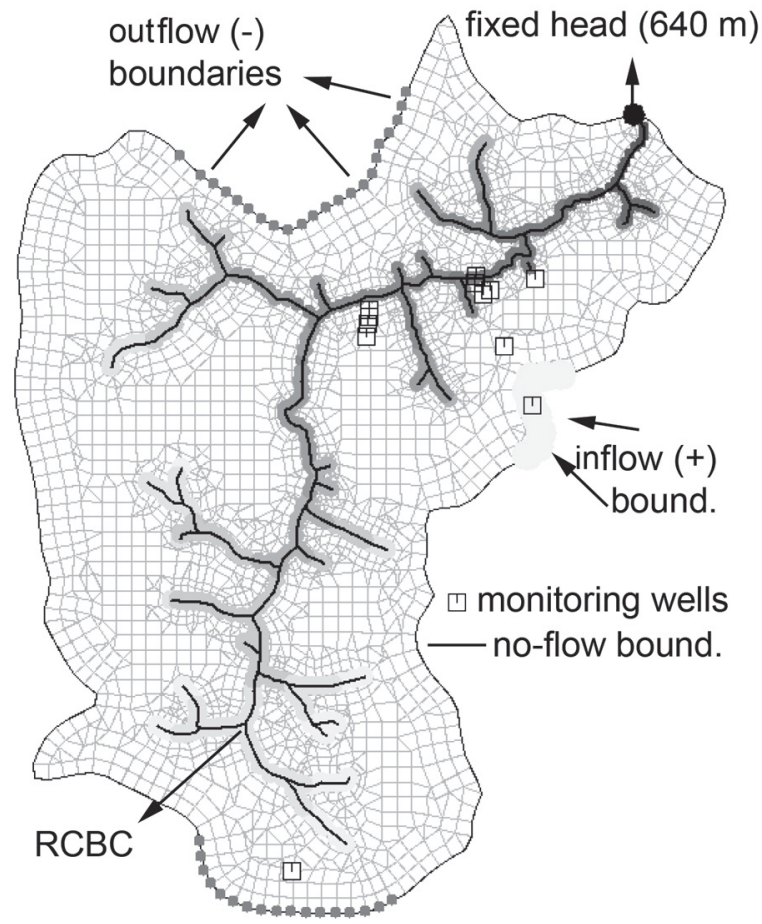

Figure 3 - SPA model domain of OCB and its boundary conditions: inflow and outflow boundaries. Drainages were set as RCBC (Robin-Cauchy Boundary Condition), except for the outlet point, set as a fixed head so the model would provide a single unique solution.

stretch was set to zero and the leakage coefficient at the nodes was adjusted through trial and error. River stage elevations were extracted from a digital elevation model derived from the Shuttle Radar Topography Mission (SRTM).

However, SRTM images are too coarse to extract river elevations within a small basin such as the OCB, a fact that became evident after running the first transient simulations. To overcome this limitation, the river stage values were adjusted considering the SRTM precision ranges.

The recharge rates used as inputs in the groundwater numerical model were estimated by the water budget method adapted by Melo et al. (2015). The calibration of the numerical model (e.g., specific yield and hydraulic conductivity) constructed by Melo et al. (2015) comprised the period between 2004 and 2011. To validate that calibration, the authors used water table levels 
measured from 2011 to 2014 and monthly averaged baseflow values from $10 / 2008$ to $09 / 2012$. To compute the baseflow, a recursive digital filter proposed by Nathan and MacMahon (1990) was used.

\section{RESULTS AND DISCUSSION}

PRECIPITATION AND TEMPERATURE - CONTROL PERIOD (1971-1999)

The precipitation $(P)$ and temperature $(T)$ regime simulated by the GCMs in the control period (19711999) were assessed with the objective of verifying their general ability of representing long term means. The monthly means of a 29 -year long time series (Jun/1971 to Dec/1999) of both variables were computed. This is the longest period with available precipitation and temperature records in the study area and in the GCM outputs. The plots in Figure 4 show the variation of observed $P$ and $T$ given as the monthly mean plus and minus the standard deviation for the respective month. The GCMs variation range of $P$ and $T$ for the same period is shown as the grey envelope.

Compared to the GCMs simulations, the observed precipitation (Figure 4a) shows a larger variability on every season, mainly in the dry seasons (April to August). For the most months, precipitation simulated by the GCMs is underestimated. On the other hand, the plot of temperature range depicts an opposite behaviour (Figure $4 b$ ). While the observed temperature has an almost constant variation range around the mean (standard deviation barely changes for all months), such variable simulated by GCMs shows a wider range. Despite the existence of extreme scenarios that cause large amplitude, the monthly mean temperature of the GCMs were closer to those obtained from the observed values than in the case of precipitation.

Such result is expected as GCMs are known for representing some variables better than others.
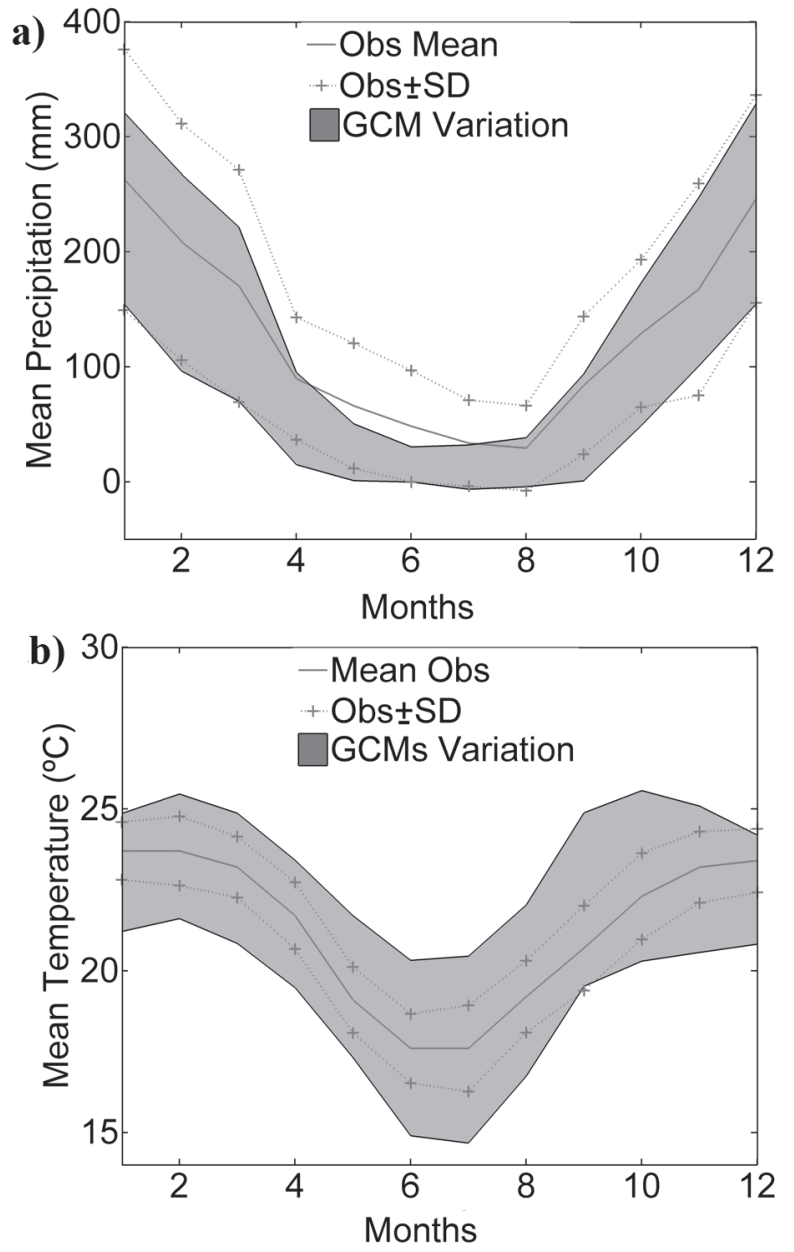

Figure 4 - Long term monthly means of observed (red lines) and simulated (grey envelope) precipitation (1971-1999) (a) and temperature (1974-1999) (b).

The limitation of poor representation of local precipitation was already noted and reported in previous studies (Trigo and Palutikof 2001, Dai 2006, Chiew et al. 2009, Jiang et al. 2013).

\section{PRECIPITATION AND TEMPERATURE - FUTURE SCENARIOS (2081-2099)}

To quantify future changes (2081-2099) in the climate scenarios, the monthly mean changes in precipitation $\left(P_{\mathrm{dw}, \mathrm{m}} / P_{\mathrm{obs}}\right)$ and temperature $\left(T_{\mathrm{dw}, \mathrm{m}}-T_{\mathrm{obs}}\right)$ were calculated using downscaled data. The plots in Figure 5 indicate an increase in the monthly mean rainfall when $P_{\mathrm{dw}, \mathrm{m}} / P_{\mathrm{obs}}>1$. In Figure $6, T_{\mathrm{dw}, \mathrm{m}}{ }^{-}$ 
$T_{\text {obs }}>0$ indicates an increase in the monthly mean temperature.

Both plots in Figure 5 show that most GCMs expect little change (less than $\pm 30 \%$ ) in precipitation for the wet season (October to March) but they usually disagree for the dry season (April to September). In Figure 5a, the five GCMs scenarios show increase of mean precipitation, at least, in two of the dry months. The most extreme scenario is from the CSIRO MK3.5 model, which projects up to 3.5 time increase in the monthly mean precipitation in July. In Figure 5b, almost all scenarios (except the GCM MIROC H for June) estimate a reduction in the precipitation monthly means. The most pessimistic scenario is from the GFDL CM2.1 model. According to this GCM, the mean precipitation will decrease for all months and have more than $80 \%$ of reduction in October $\left(P_{\mathrm{dw}, \mathrm{m}}\right)$ $\left.P_{\text {obs }}=0.16\right)$.

Monthly mean changes in temperature are shown in Figure 6. The CGCM.T47 model (Figure 6b) is the only one to estimate monthly mean temperatures similar to the observed ones. Temperatures from the GCM MIROC H (Figure 6b) present a different behaviour compared to the other climate models, projecting stronger warming for the wet season $\left(3<T_{\mathrm{dw}, \mathrm{m}}-T_{\mathrm{obs}}<6{ }^{\circ} \mathrm{C}\right)$ and an increase of $\sim 2{ }^{\circ} \mathrm{C}$ for the other months. GCMs CCSM3, CNRM CM3 and CSIRO Mk3.5 (Figure 6a) presented a similar behaviour: temperature rises would be larger during the dry season (with little variation) and less warming will occur during the rest of the year. The other GCMs' monthly temperature means presented an oscillatory behaviour but, in general, a common feature among the great majority of those $\mathrm{GCMs}$ is the increase in temperature of $\sim 2$ to $6^{\circ} \mathrm{C}$.

\section{GROUNDWATER MODEL CALIBRATION AND VALIDATION}

Hydraulic conductivity $(K)$ is widely variable within GAS, ranging from $2.6 \times 10^{-6}$ to $1.9 \times 10^{-3}$ $\mathrm{m} \mathrm{s}^{-1}$ (Sracek and Hirata 2002, Araújo et al. 1999)
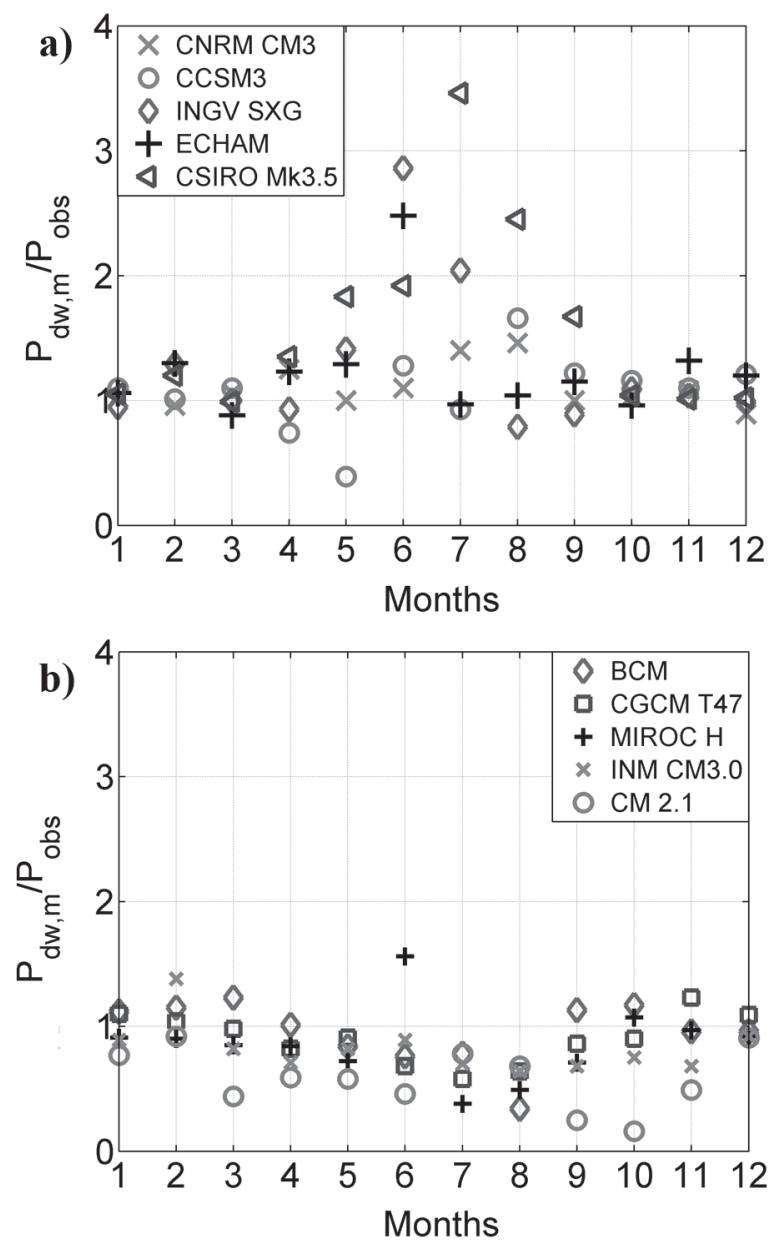

Figure 5 - Monthly mean changes in precipitation $\left(\mathrm{P}_{\mathrm{dw}, \mathrm{m}}\right)$ for the 10 future scenarios (2081-2099) divided by the observed precipitation $\left(\mathrm{P}_{\mathrm{obs}}\right)$ during the control period (1971-1999).

while specific yield $\left(S_{\mathrm{y}}\right)$ varies from 7 to $15 \%$ (Sracek and Hirata 2002, Wendland et al. 2015). The initial values of such parameters were set in accordance to previous estimates (Sracek and Hirata 2002). After calibration of the model the hydrogeological parameters were found to vary within $2.6 \times 10^{-6}$ to $3.0 \times 10^{-5} \mathrm{~m} \mathrm{~s}^{-1}(K)$ and 7.5 to $14.5 \%\left(S_{\mathrm{y}}\right)$ in the watershed.

The calibration results of the groundwater model are shown as a scatter plot of measured groundwater heads versus simulated heads in SPA (Figure 7). The mean error of the simulated heads was $0.59 \mathrm{~m}$ and the Root Mean Squared Error (computed with a 1102 sample size) was $1.52 \mathrm{~m}$. 

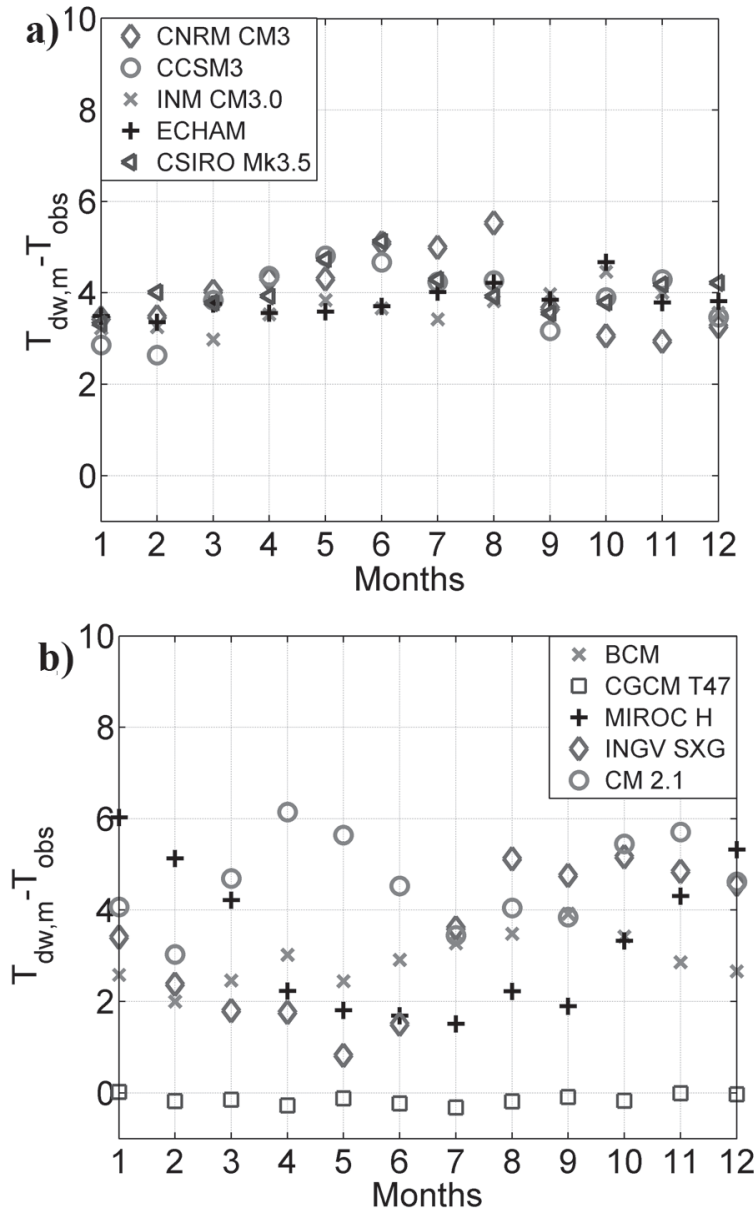

Figure 6 - Monthly mean changes in precipitation $\left(\mathrm{T}_{\mathrm{dw}, \mathrm{m}}\right)$ for the 10 future scenarios (2081-2099) divided by the observed precipitation ( $\mathrm{T}_{\mathrm{obs}}$ ) during the control period (1971-1999).

Daily baseflow estimated using a digital filter (Nathan and McMahon 1990) is shown in Figure 8 along with the monthly averages produced as outputs in the transient groundwater flow model (SPA). Both results suggest that the model calibration is satisfactory, although some shortterm variations of baseflow might not be captured by the SPA model. This is indeed expected, given that such oscillations are due to the daily time scale of the observed records used in the filter while the outputs of SPA have a monthly time scale.

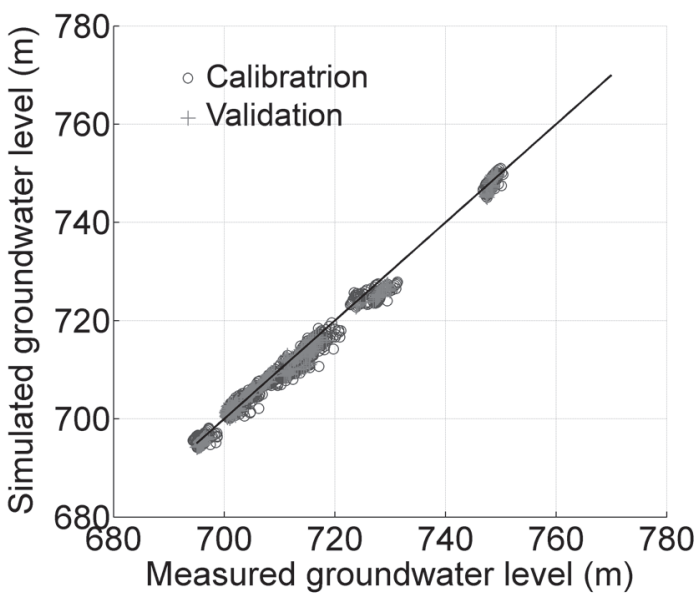

Figure 7 - Comparison of measured water levels and water levels simulated by SPA transient groundwater model during calibration (circle) and validation (cross) periods.

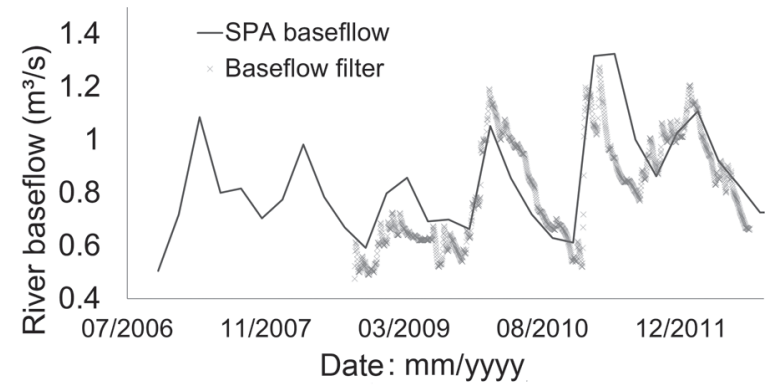

Figure 8 - Baseflow simulated by SPA groundwater model and estimated using a digital filter.

\section{IMPACT OF CLIMATE CHANGE ON GROUNDWATER RECHARGE}

The impacts of climate change on groundwater recharge (GWR) were assessed by comparing the annual mean estimates for the main land use types between the control period (1971-1999) and those from the future scenarios (2081-2099). The results of such analysis are shown in Table I, which displays the average estimated recharge in OCB for the period between 1971 and 1999. The percentage change for each scenario is shown for the future period of 2081-2099. 
TABLE I

Annual mean recharge calculated by the water budget using observed data and percentual change in mean recharge for future scenarios.

\begin{tabular}{ccccc}
\hline \multirow{2}{*}{$\begin{array}{c}\text { Annual Mean } \\
\text { Recharge }\end{array}$} & \multicolumn{4}{c}{ Land Use } \\
\cline { 2 - 5 } Cane & Citrus & Eucalyptus & Pasture \\
\hline $\begin{array}{c}\text { Observed } \\
\text { Data (mm) }\end{array}$ & 255.68 & 466.62 & 284.04 & 375.18 \\
\hline GCM & Percentual change in annual mean \\
recharge (\%) \\
\hline BCM & -15.42 & +7.96 & -16.58 & +17.12 \\
CCSM3 & -28.17 & +5.65 & -16.56 & +12.32 \\
GFDL CM2.1 & -75.10 & -55.90 & -63.28 & -60.64 \\
CNRM CM3 & -61.42 & -34.44 & -51.46 & -30.42 \\
ECHAM & +3.63 & +33.45 & +8.10 & +45.03 \\
INM CM3.0 & -51.81 & -24.48 & -39.64 & -25.29 \\
CSIRO Mk3.5 & +15.40 & +43.42 & +16.63 & +58.64 \\
INGV SXG & -13.59 & +6.64 & -10.60 & +13.50 \\
CGCM T.47 & +20.22 & +28.68 & +0.58 & +48.56 \\
MIROC H & -82.90 & -54.00 & -62.96 & -62.66 \\
\hline
\end{tabular}

The estimates of annual mean recharge in the control period ranged from $250 \mathrm{~mm}$ (Sugarcane) to $470 \mathrm{~mm}$ (Citrus). These results agree with the averages reported by Lucas et al. (2012), who applied the Water Table Fluctuation method using data from monitoring wells located in areas of sugarcane, pasture, eucalyptus and citrus inside OCB or near OCB borders.

Recharge would be mostly affected by the scenarios by GFDL CM2.1, CNRM CM3, INM CM3.0 and MIROC H. According to their projections, a reduction in GWR between $24 \%$ and $82 \%$ could be experienced. Less pessimistic scenarios (CCSM3, for instance) resulted in reductions in GWR of up to $28 \%$ and a minimum increase of around $5 \%$. The positive percentage change can be even larger, as it can be seen for the CGCM T47 (GWR $\leq 48 \%)$ and ECHAM (GWR $\leq$ $45 \%$ ) projections.

The more optimistic scenarios are from ECHAM, CSRIO MK3.5, CGCM T47, which projected increase of mean GWR for most of the analysed land uses. In general, the less negatively affected land uses are citrus and pasture, possibly because of their relative lower evapotranspiration rates combined with its smaller size (pasture) or lower areal density (citrus).

It is interesting to note the wide range of responses in these estimates: $-82.9 \%$ (MIROC $\mathrm{H}$, sugarcane) $\leq \mathrm{GWR} \leq+8.6 \%$ (CSIRO MK3.5, pasture). Some regional studies reviewed by Kurylyk and McQuarrie (2013) reported similar ranges of changes in recharge $(\sim 140 \%)$, such as that by Serrat-Capdevila et al. (2007) (-100\% to $\sim+35 \%$ ), or even larger, such as Crosbie et al. (2011) $(-83 \%$ to $\sim 447 \%)$. This fact is a strong indicator of the uncertainties that exist amongst scenarios and, as noted in past studies (Holman et al. 2006, Kurylyk and McQuarrie 2013), show the importance of using multiple scenarios in this type of analysis.

IMPACT OF CLIMATE CHANGE ON GROUNDWATER LEVELS (2081-2099)

The two most pessimistic and optimistic scenarios (MIROC H and CSIRO Mk3.5) were selected to estimate the spatial impacts on GWL in the OCB under the current land uses. Figure 9 shows results, obtained for permanent flow regime (steady-state run) fed with long term recharge estimates. The optimistic scenario (CSIRO Mk3.5) would result in groundwater elevations between 0 and $15 \mathrm{~m}$. The pessimist scenario (MIROC $\mathrm{H}$ ) would make the water table decline more than $30 \mathrm{~m}$.

Transient simulations were used to evaluate the impacts on groundwater levels (GWL) considering the current land uses and the land uses scenario described in the methodology. In all of the scenarios the land use along the river channels was not changed, as Brazilian legislation forbids the removal of natural vegetation from riparian areas.

The plots in Figures 10 and 11 show the responses given by the SPA model using the 

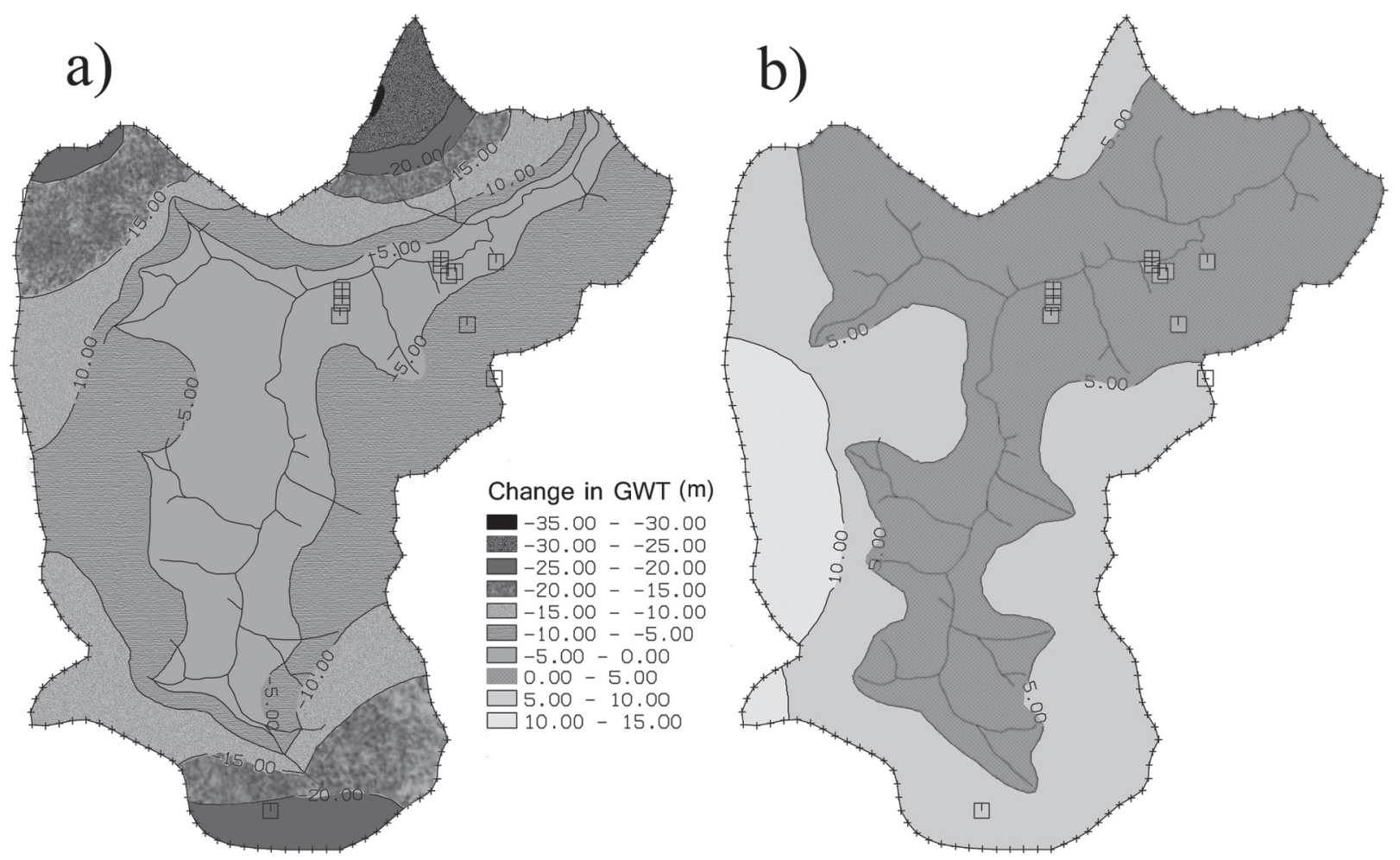

Figure 9 - Spatial changes in groundwater table under a pessimistic (MIROC H) (a) and optimistic (CSIRO Mk3.5) (b) scenario. These changes are the results for steady-state runs considering long-term (2081-2099) averages of recharge estimates.

recharge estimates computed under the climate scenarios. Three monitoring wells located in areas of citrus (Well 13), sugarcane cane (Well 8) and pasture (2004-2011)/eucalyptus (2011-2014) (Well 17) were chosen to present the groundwater level variation in the OCB. During the monitoring period (2004-present) the land use around the wells 16 to 19 changed from pasture to eucalyptus in 2011.

The dashed lines represent the numerical results for the most optimistic and pessimistic scenarios, classified as such based on the mean water table level in the future. The results for the first 2000 days of simulation were discarded, assuming that this is a sufficient "warm-up" period for the numerical model. The measured levels from 2004 to 2011 are also plotted (red crosses) to assist the analysis.

For the current land use (Figure 10), the climate scenarios resulted in a wide variety of responses, but most of them suggest that the GWL will continuously drop and oscillate in a lower level. It can be seen that there is a downward trend, especially for the wells in the citrus and sugarcane areas. The majority of the simulated scenarios resulted in a lowering of the GWL, matching the measured levels in years of reduced rainfall (20122013, for instance).

The model run for a land use scenario of total occupation by sugar cane (Figure 11) resulted in larger GWL lowering. This behaviour is expected given the high evapotranspiration rates of such culture. It can also be noted that most of the climate scenarios resulted in a smaller variation range than that of Figure 10.

Given the large variability of GWL over time, the intra-annual impacts may assist the impact assessment analysis by comparing the monthly mean measured levels against the respective average model results. 

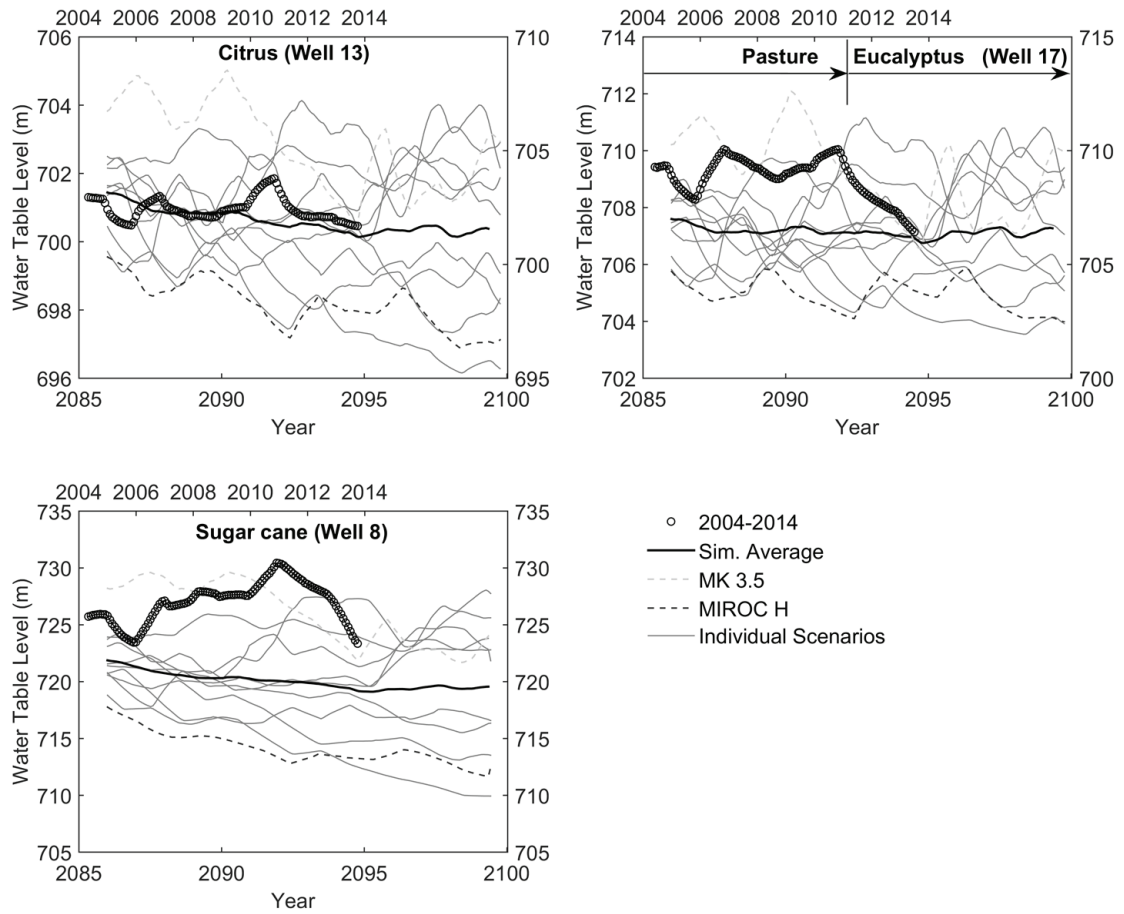

Figure 10 - Moving average of observed (circles) and simulated (lines) hydrographs in three wells for the 2004-2014 land use. The land use around well 17 has changed from pasture to eucalyptus in 2011.
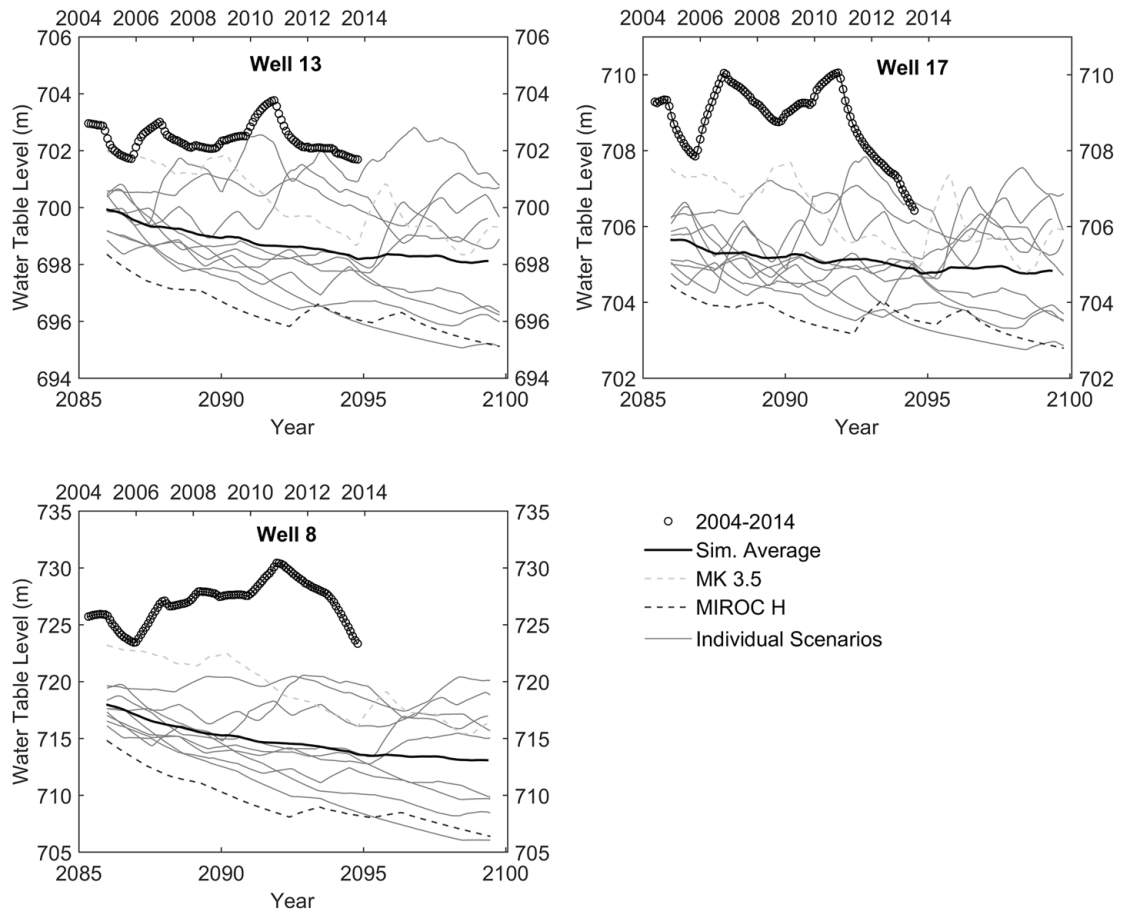

Figure 11 - Moving average of observed (circles) and simulated (lines) hydrographs in three wells considering the proposed land use change (sugarcane). 

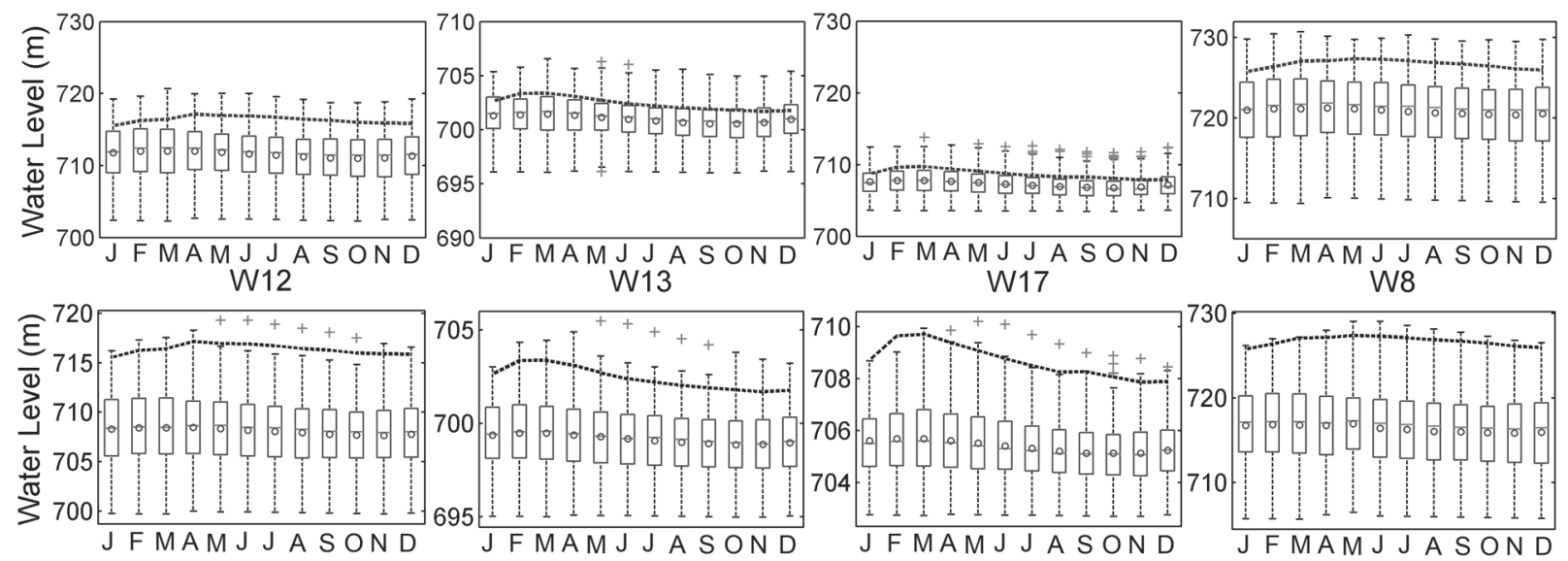

Figure 12 - Monthly means of observed (dashed line) and simulated (box-plot) water levels in the monitoring wells for the 20042014 land use (upper graphs) and proposed land use change (bottom graphs).

The intra-annual impacts are shown in Figure 12 considering four representative monitoring wells. Knowing that the data represented by the box accounts for $50 \%$ of the sample (first and third quartile) and that the circle stands for the mean, some features can be identified. The monthly GWL variation was larger (more than $15 \mathrm{~m}$ ) in the wells 8 and 12. One could infer that such characteristic might be related to the sugarcane plantings, where well 8 is inserted. Well 12 is located in the transition between sugarcane and citrus plantings. However, both wells are near the topographic divisors, where the water table is deeper and the losses by groundwater evapotranspiration tend to zero. Hence, higher fluctuation is expected. This explanation can be supported by the fact that the maximum GWL in both wells happens with a twomonth lag (April and May) in comparison to the other wells (February and March).

Despite the large variability among the input scenarios, the responses obtained at well 17 were similar (short boxes), indicating that those areas are less sensitive to climate signals.

The results of the model run considering the second land use scenario (sugarcane) are shown by the bottom plots in Figure 12. Under that assumption, only a minority of GCMs would result in GWL close to the observed monthly means. As exemplified by the boxplots of the well 17, the observed levels (dashed line) fluctuate around the upper whiskers.

In both scenarios, there are few outliers and the great majority of them appear above the whiskers, pointing to two important observations: (i) although some climatic scenario led to a wide variety of responses, the results do not incorporate that apparent divergence. Thus, the impacts generated by those GCMs are convergent and indicate that the GWL will be negatively affected by the climate changes; (ii) there are almost no outliers below the lower whiskers suggesting that even the more pessimistic GCM led to similar results as the optimistic ones. Thus, there is only a small minority of projections that led to a less critical condition, suggesting that the water availability is likely to be reduced.

\section{CONCLUSIONS}

The impacts of ten future climate change scenarios on groundwater levels in a representative region of the Guarani Aquifer outcrop zone were assessed. Those projections were combined with two land use scenarios. The impacts were evaluated in terms of change in precipitation, temperature, groundwater recharge and groundwater table levels. The authors 
applied a water budget method to estimate recharge rates under different land uses, which were used as input in a groundwater model.

The majority of the future climate scenarios projects decrease in monthly mean precipitation. A few scenarios suggest that meaningful increase can occur during the dry season. Only one GCM projected reduction of monthly mean temperatures. Most of the scenarios agree that the temperature will rise more than $2^{\circ} \mathrm{C}$ all months. According to five of the analysed GCMs, warming during the dry season will be larger than in the wet season. For our study area, this means that the evapotranspiration rates during the Winter (dry season) will increase significantly.

Under the analysed scenarios, groundwater recharge (GWR) will be mostly negatively affected in areas with sugarcane plantings and eucalyptus, since most scenarios resulted in reduction of GWR. For all existing land uses, the negative impacts (less water availability) of climate change on recharge will be larger than the positive ones. Most of the climate scenarios used in this study predicts reduction on recharge which, by turn, causes the lowering of groundwater levels.

The Guarani Aquifer System has a great potential for supplying the future generations with water. However, the findings reported here suggest that this potentiality can be compromised in many levels. Assuming that the impacts estimated for the Onça Creek basin are representative to other recharge areas of GAS, it is necessary to consider the possibility that the future replenishment of the aquifer can be significantly reduced. This may not only reduce the total water availability but may also result in a higher energy demand to compensate the decrease of piezometric head in the confined parts of the GAS.

Another implication is related another anthropic forcing: land use change. The projected increase in temperatures is not the only one factor that will increase evapotranspiration but also the agricultural uses, making it an important factor to be accounted for in the future. Although runoff has a minor role compared to evapotranspiration in our study area, this might be very different as the land use changes. For instance, despite the high evapotranspiration rates of sugarcane plantings, such culture has a positive impact on runoff whereas the opposite is observed in bare soils (Youlton 2013). Oliveira et al. (2015) reported significant increase of runoff as a consequence of removal of native forests (Brazilian Cerrado). Thus, it is important to control the expansion of sugarcane and other agricultural uses with high water demand in the GAS outcrop zone as well as of those that increase runoff rates.

\section{ACKNOWLEDGMENTS}

This study was supported by the Conselho Nacional de Desenvolvimento Científico e Tecnológico (CNPq). The authors are thankful to the constructive suggestions by the anonymous reviewers.

\section{REFERENCES}

ALLEN GR, PEREIRA LS, RAES D AND SMITH M. 1998. Crop Evapotranspiration (guidelines for computing crop water requirements). Rome: Food and Agriculture Organization of the United Nations. (FAO Irrigation and Drainage Paper, 56).

ARAÚJO LM, FRANÇA AB AND POTTER PE. 1999. Hydrogeology of the Mercosul aquifer system in the Paraná and Chaco-Paraná Basins, South America, and comparison with the Navajo-Nugget aquifer system, USA. Hydrogeol J 7(3): 317-336.

BARRETT R, BERRY M, CHAN TC, DEMMEL J, DONATO J, DONGARRA J, EIJKHOUT V, POZO R, ROMINE C AND VAN DER VORST H. 1994. Templates for the solution of linear systems: Building blocks for iterative methods. Philadelphia: SIAM, 2nd ed.

BEAR J. 1979. Hydraulics of groundwater. McGraw-Hill International Book Co. Mineola, NY, 569 p.

BERG P, FELDMANN H AND PANITZ HJ. 2012. Bias correction of high resolution regional climate model data. J Hydrol 448: 80-92.

CHIEW FHS AND MCMAHON TA. 2002. Modelling the impacts of climate change on Australian streamflow. Hydrol Process 16(6): 1235-1245. 
CHIEW FHS, TENG J, VAZE J AND KIRONO DGC. 2009. Influence of global climate model selection on runoff impact assessment. J Hydrol 379(1-2): 172-180.

CROSBIE RS, DAWES WR, CHARLES SP, MPELASOKA FS, ARYAL S, BARRON O AND SUMMERELL GK. 2011. Differences in future recharge estimates due to GCMs, downscaling methods and hydrological models. Geophys Res Lett 38(11): L11406.

DAI A. 2006. Precipitation Characteristics in Eighteen Coupled Climate Models. J Clim 19(18): 4605-4630.

DAMS J, SALVADORE E, VAN DAELE T, NTEGEKA V, WILLEMS P AND BATELAAN O. 2012. Spatiotemporal impact of climate change on the groundwater system. Hydrol Earth Syst Sc 16(5): 1517-1531.

DAWES W, ALI R, VARMA S, EMELYANOVA I, HODGSON G AND MCFARLANE D. 2012. Modelling the effects of climate and land cover change on groundwater recharge in south-west Western Australia. Hydrol Earth Syst Sc 9(5): 6063-6099.

ECKHARDT K AND ULBRICH U. 2003. Potential impacts of climate change on groundwater recharge and streamflow in a central European low mountain range. J Hydrol 284(14): 244-252.

FETTER CW. 2001. Applied Hydrogeology. 4th ed., EUA: Prentice-Hall, New York, 598 p.

FICKLIN DL, LUEDELING E AND ZHANG M. 2010. Sensitivity of groundwater recharge under irrigated agriculture to changes in climate, $\mathrm{CO} 2$ concentrations and canopy structure. Agr Water Manage 97(7): 1039-1050.

GEORGE PL AND SEVENO E. 1994. The advancing-front mesh generation method revised. Int J Numer Meth Eng 37: 3605-3619.

GIORDANO M. 2009. Global Groundwater? Issues and Solutions. Annu Rev Environ Resour Palo Alto: Annual Reviews, p. 153-178.

HIRATA R, GESICKI A, SRACEK O, BERTOLO R, GIANNINI PC AND ARAVENA R. 2011. Relation between sedimentary framework and hydrogeology in the Guarani Aquifer System in São Paulo state, Brazil. J S Am Earth Sc 31(4): 444-456.

HOLMAN IP. 2006. Climate change impacts on groundwater recharge-uncertainty, shortcomings, and the way forward? Hydrogeol J 14(5): 637-647.

HOLMAN IP, TASCONE D AND HESS TM. 2009. A comparison of stochastic and deterministic downscaling methods for modelling potential groundwater recharge under climate change in East Anglia, UK: implications for groundwater resource management. Hydrogeol J 17(7): 1629-1641.

JIANG P, GAUTAM MR, ZHU J AND YU Z. 2013. How well do the GCMs/RCMs capture the multi-scale temporal variability of precipitation in the Southwestern United States? J Hydrol 479: 75-85.
JOHNSON R AND JELMAYER R. 2015. Facing drought, Brazil enters risky waters. The Wall Street Journal, 7 April, p. A9 World News.

JYRKAMA MI AND SYKES JF. 2007. The impact of climate change on spatially varying groundwater recharge in the grand river watershed (Ontario). J Hydrol 338(3-4): 237 250.

KIDMOSE J, REFSGAARD JC, TROLDBORG L, SEABY LP AND ESCRIVÀ MM. 2013. Climate change impact on groundwater levels: ensemble modelling of extreme values. Hydrol Earth Syst Sc 9(6): 7835-7875.

KURYLYK BL AND MACQUARRIE KTB. 2013. The Uncertainty Associated with Estimating Future Groundwater Recharge: A Summary of Recent Research and an Example from a Small Unconfined Aquifer in a Northern Humid-Continental Climate. J Hydrol 492: 244253.

KURYLYK BL, MACQUARRIE KTB AND VOSS CI. 2014. Climate Change Impacts on the Temperature and Magnitude of Groundwater Discharge from Shallow, Unconfined Aquifers. Water Resour Res 50(4): 3253-3274.

KWON H-H, SOUZA FILHO FA, BLOCK P, SUN L, LALL U AND REIS JR DS. 2012. Uncertainty assessment of hydrologic and climate forecast models in Northeastern Brazil. Hydrol Process 26(25): 3875-3885.

LEGESSE D, VALLET-COULOMB C AND GASSE F. 2003. Hydrological response of a catchment to climate and land use changes in Tropical Africa: case study South Central Ethiopia. J Hydrol 275(1-2): 67-85.

LIU H-H. 2011. Impact of climate change on groundwater recharge in dry areas: An ecohydrology approach. J Hydrol 407(1-4): 175-183.

LUCAS MC, GUANABARA RC AND WENDLAND E. 2012. Estimating groundwater recharge in the outcrop area of the Guarani Aquifer System. B Geol Min 123(3): 311323.

MACHADO AR, WENDLAND E AND KRAUSE P. 2016. Improving water balance in an outcrop area of the Guarani Aquifer System through hydrologic simulation. Environ Process 3: 19-38.

MCCALLUM JL, CROSBIE RS, WALKER GR ANDDAWES WR. 2010. Impacts of climate change on groundwater in Australia: a sensitivity analysis of recharge. Hydrogeol J 18(7): 1625-1638.

MEDEIROS PV, MARCUZZO FFN, YOULTON C AND WENDLAND E. 2012. Error autocorrelation and linear regression for temperature-based evapotranspiration estimates improvement. J Am Water Res Assoc 48: $297-$ 305.

MEEHL GA, COVEY C, TAYLOR KE, DELWORTH T, STOUFFER RJ, LATIF M, MCAVANEY B AND MITCHELL JFB. 2007. The WCRP CMIP3 Multimodel 
Dataset: A new era in climate change research. Bull Amer Meteor Soc 88(9): 1383-1394.

MELO DCD, WENDLAND E AND GUANABARA RC. 2015. Estimate of groundwater recharge based on water balance in the unsaturated soil zone. Rev Bras Cienc Solo 39(5): 1-9.

MOUSTADRAF J, RAZACK M AND SINAN M. 2008. Evaluation of the impacts of climate changes on the coastal Chaouia aquifer, Morocco, using numerical modeling. Hydrogeol J 16(7): 1411-1426.

NAKICENOVIC N ET AL. 2000. IPCC Special Report on Emissions Scenarios (SRES). UK: Cambridge University Press.

NATHAN RJ AND MCMAHON TA. 1990. Evaluation of automated techniques for base flow and recession analyses. Water Resour Res 26(7): 1465-1473.

NATKHIN M, STEIDL J, DIETRICH O, DANNOWSKI R AND LISCHEID G. 2012. Differentiating between climate effects and forest growth dynamics effects on decreasing groundwater recharge in a lowland region in northeast germany. J Hydrol (448-449): 245-254.

NEUKUM C AND AZZAM R. 2012. Impact of climate change on groundwater recharge in a small catchment in the Black Forest, Germany. Hydrogeol J 20(3): 547-560.

OAS/GEF - ORGANIZATION OF AMERICAN STATES/ GLOBAL ENVIRONMENT FACILITY. 2009. Proyecto para la Protección Ambiental y Desarrollo Sostenible del Sistema Acuífero Guaraní. Montevideu, Uruguay.

OLIVEIRA PTS, WENDLAND E, NEARING MA, SCOTT RL, ROSOLEM R AND DA ROCHA HR. 2015. The water balance components of undisturbed tropical woordlands in the Brazilian cerrado. Hydrol Earth Syst Sc 19: 2899-2910.

PRASKIEVICZ S AND CHANG H. 2009. A Review of Hydrological Modelling of Basin-Scale Climate Change and Urban Development Impacts. Prog Phys Geog 33(5): 650-671.

RABELO JL AND WENDLAND E. 2009. Assessment of groundwater recharge and water fluxes of the Guarani Aquifer System, Brazil. Hydrogeol J 17(7): 1733-1748.

RAPOSO JR, DAFONTE J AND MOLINERO J. 2013. Assessing the impact of future climate change on groundwater recharge in Galicia-Costa, Spain. Hydrogeol J 21(2): 459-479.

ROMERO S. 2015. Taps start to run dry in Brazil's largest city. The New York Times, 17 February, p. A4 Americas.

ROZELL DJ AND WONG T-F. 2010. Effects of climate change on groundwater resources at Shelter Island, New York State, USA. Hydrogeol J 18(7): 1657-1665.
RUDORFF BFT, AGUIAR DA, SILVA WF, SUGAWARA LM, ADAMI M AND MOREIRA MA. 2010. Studies on the rapid expansion of sugarcane for ethanol production in São Paulo State (Brazil) using Landsat data. Remote Sens 2(4): 1057-1076.

SCIBEK J, ALLEN DM, CANNON AJ AND WHITFIELD PH. 2007. Groundwater-surface water interaction under scenarios of climate change using a high-resolution transient groundwater model. J Hydrol 333(2-4): 165-181.

SERRAT-CAPDEVILA A, VALDÉS JB, PÉREZ JG, BAIRD K, MATA LJ AND MADDOCK III T. 2007. Modeling climate change impacts - and uncertainty - on the hydrology of a riparian system: The San Pedro Basin (Arizona/Sonora). J Hydrol 347: 48-66.

SRACEK O AND HIRATA R. 2002. Geochemical and stable isotopic evolution of the Guarani Aquifer System in the state of Sao Paulo, Brazil. Hydrogeol J 10(6): 643-655.

TEUTSCHBEIN C AND SEIBERT J. 2012. Bias correction of regional climate model simulations for hydrological climate-change impact studies: Review and evaluation of different methods. J Hydrol 456: 12-29.

THORNTHWAITE CW. 1948. An approach toward a rational classification of climate. Geog Review 38: 55-94.

TOEWS MW AND ALLEN DM. 2009. Simulated Response of Groundwater to Predicted Recharge in a Semi-Arid Region Using a Scenario of Modelled Climate Change. Environ Res Lett 4: 035003.

TRIGO RM AND PALUTIKOF JP. 2001. Precipitation Scenarios over Iberia: A Comparison between Direct GCM Output and Different Downscaling Techniques. J Clim 14(23): 4422-4446.

WENDLAND E, GOMES LH AND TROEGER U. 2015. Recharge contribution to the Guarani Aquifer System estimated from the water balance method in a representative watershed. An Acad Bras Cienc 87: 595-609.

WENDLAND EC. 2003. Implementação de pacote computacional SPA (Simulação de Processos em Aquíferos). Relatório de Pesquisa FAPESP 02/09696-3, Universidade de São Paulo, Brasil.

WILLEMS P AND VRAC M. 2011. Statistical precipitation downscaling for small-scale hydrological impact investigations of climate change. J Hydrol 402(3-4): 193205.

YOULTON C. 2013. Quantificação experimental da alteração no balanço hídrico e erosão em um neossolo quartzarênico devido à substituição de pastagem por cana-de-açúcar. Ph.D. Thesis, Universidade de São Paulo, São Carlos, SP, Brasil. 